\title{
Hidden rheumatoid factor in seronegative juvenile rheumatoid arthritis
}

\author{
T. MOORE, R. W. DORNER, AND J. ZUCKNER \\ From the Section of Arthritis, Departments of Internal Medicine and Biochemistry, St. Louis University \\ School of Medicine, St. Louis, Missouri 63104, U.S.A.
}

The incidence of rheumatoid factor (RF) in juvenile rheumatoid arthritis (JRA) has been studied and correlated with clinical findings by Bywaters, Carter, and Scott (1959), Cassidy and Valkenburg (1967), and Hanson, Drexler, and Kornreich (1969). It is generally accepted that about 20 per cent. of patients with JRA have RF in their serum compared to 75 per cent. or more of patients with rheumatoid arthritis of adult onset. The discovery by Allen and Kunkel (1966), subsequently extended by Bluestone, Goldberg, and Cracchiolo (1969) and Cracchiolo, Bluestone, and Goldberg (1970), that certain apparently seronegative patients with rheumatoid arthritis have 'hidden' RF in their serum suggested the investigation of seronegative patients with JRA for the possible presence of 'hidden' RF. Allen and Kunkel (1966) had considered this possibility, but their 'initial studies with these techniques on serum from children with JRA failed to uncover agglutinating activity'. The present data show that about 40 per cent. of JRA patients had 'hidden' RF in their sera.

\section{Material and methods}

Sera were obtained from seronegative JRA patients at the Arthritis Clinic of Cardinal Glennon Memorial Hospital for Children. Clinical information on these patients is presented in Table I. Most of them did not have eye involvement, had positive ANA titres, and had polyarticular onset of disease.

Gel filtration was performed on a Sephadex G-200 column $(2.5 \times 85 \mathrm{~cm}$.) essentially by the method of Allen and Kunkel (1966). Samples of sera (usually $3 \mathrm{ml}$.) were added to the column and eluted with $0.1 \mathrm{~m}$ sodium acetate buffer, $\mathrm{pH} 4.05$ (pressure head $8 \mathrm{~cm}$.). The column effluent was continuously monitored by determining the absorbance at $280 \mathrm{~nm}$., and 200 drop-samples were collected on a fraction collector. The three major elution peaks resulting from gel filtration of serum in these conditions, which obviously contain mixtures of proteins, will be referred to as IgM-, IgG- and albumin-fractions according to their principal constituent. Immunodiffusion assays revealed the presence of traces of IgG in the IgM fraction while the IgG fraction was free from IgM. Some sera yielded an additional protein peak intermediate

Acceoted for publication September 24, 1973.

This paper was presented at the Regional Meeting of the American College of Physicians, St. Louis, Missouri, February 23, 1973.

Table I Clinical data on patients with seronegative juvenile rheumatoid arthritis

\begin{tabular}{|c|c|c|c|c|c|c|c|}
\hline $\begin{array}{l}\text { Patient } \\
\text { no. }\end{array}$ & Sex & $\begin{array}{l}\text { Age at } \\
\text { onset } \\
\text { (yrs) }\end{array}$ & $\begin{array}{l}\text { Duration } \\
\text { of disease } \\
\text { (yrs) }\end{array}$ & $\begin{array}{l}E S R \dagger \\
(\mathrm{mm} . / \mathrm{hr})\end{array}$ & $\begin{array}{l}A N A_{\ddagger}^{\ddagger} \\
\text { (titre) }\end{array}$ & $\begin{array}{l}\text { Type of } \\
\text { onset } \$ \\
\text { (joint) }\end{array}$ & $\begin{array}{l}A R A \\
\text { stage\| } \\
\text { class }\end{array}$ \\
\hline $\begin{array}{c}1 \\
2 \\
3 \\
4 \\
5 \\
6 \\
7 \\
89 \\
99 \\
10 \\
11 \\
12 \\
13\end{array}$ & $\begin{array}{l}\mathbf{M} \\
\mathbf{M} \\
\mathbf{F} \\
\mathbf{F} \\
\mathbf{F} \\
\mathbf{F} \\
\mathbf{F} \\
\mathbf{F} \\
\mathbf{F} \\
\mathbf{F} \\
\mathbf{F} \\
\mathbf{M} \\
\mathbf{F}\end{array}$ & $\begin{array}{r}4 \\
7 \\
9 \\
5 \\
13 \\
9 \\
13 \\
2 \\
4 \\
7 \\
5 \\
2 \\
5\end{array}$ & $\begin{array}{r}4 \\
3 \\
3 \\
8 \\
2 \\
5 \\
4 \\
10 \\
4 \\
3 \\
9 \\
6 \\
4\end{array}$ & $\begin{array}{l}34 \\
16 \\
27 \\
22 \\
28 \\
12 \\
20 \\
69 \\
38 \\
16 \\
46 \\
4\end{array}$ & $\begin{array}{l}\text { Neg. } \\
\text { Neg. } \\
\text { Neg. } \\
1: 10 \\
1: 40 \\
\text { Neg. } \\
1: 80 \\
1: 800 \\
1: 400 \\
1: 40 \\
1: 160 \\
1: 80 \\
\text { Neg. }\end{array}$ & $\begin{array}{l}\text { Poly } \\
\text { Pauci } \\
\text { Poly } \\
\text { Poly } \\
\text { Pauci } \\
\text { Poly } \\
\text { Poly } \\
\text { Poly } \\
\text { Pauci } \\
\text { Poly } \\
\text { Poly } \\
\text { Pauci } \\
\text { Pauci }\end{array}$ & $\begin{array}{l}\text { II, I } \\
\text { II, II } \\
\text { II, II } \\
\text { III, II } \\
\text { III, III } \\
\text { II, II } \\
\text { I, I } \\
\text { II, II } \\
\text { I, II } \\
\text { II, II } \\
\text { II, II } \\
\text { I, I } \\
\text { III, I }\end{array}$ \\
\hline
\end{tabular}

* Latex test at titre of $1: 20$ or less was negative.

+ Erythrocyte sedimentation rate (Westergren).

$\mp$ Antinuclear antibody (all positive tests showed a diffuse pattern of fluorescence).

$\$$ Type of onset: poly or polyarticular (multiple joint involvement on presentation); pauci or pauciarticular (one or few joints involved

On presentation).

T Patients 8 and 9 were evaluated twice, in April and October, 1972; ANA titres were obtained only in October, the other parameters remained unchanged. 
between the IgM- and IgG-fractions. If such a peak was present, it was collected, processed, and assayed separately. Since large amounts of protein always elute between the IgM- and IgG-peaks, these small intermediate peaks may represent artefacts. Samples belonging to the albumin fraction were discarded. Fractions belonging to a protein peak were pooled, concentrated to the original serum volume by negative pressure dialysis, and dialysed against two changes of $0 \cdot 1 \mathrm{M}$ glycine buffer $\mathrm{pH} 8 \cdot 2,0 \cdot 2 \mathrm{M}$ in sodium chloride (latex buffer). The latex test was performed after heat inactivating at $56^{\circ} \mathrm{C}$. for $30 \mathrm{~min}$. essentially according to the method of Singer and Plotz (1956) with a commercial test kit $\left(^{*}\right)$ which includes positive and negative controls.

Antinuclear antibodies (ANA) were determined by an indirect fluorescent staining method using mouse kidney and fluorescein-labelled antihuman IgG antibody.

\section{Results}

The results of latex tests for RF activity in sera and in fractions of sera obtained by gel filtration at acid pH from patients with JRA are listed in Table II. Six of thirteen patients ( 46 per cent.) who had negative latex tests (i.e. titres less than $1: 20$ ) on their original serum had RF activity in titres ranging from 1:40 to $1: 160$ in the isolated IgM-fraction. Note that isolated fractions were concentrated to the original serum volume so that RF titres should be directly comparable. None of the IgG-fractions had RF activity; intermediate fractions reflected the IgM titres. It is of interest that patients 8 and 9 had no 'hidden' RF activity on the first assay, but had developed 'hidden' RF

* Bacto-Rheumatoid Titration Test, Difco Laboratories, Detroit, Michigan.

Table II Assay for rheumatoid factor from gel filtration on Sephadex G-200 at acid pH of serum from thirteen patients with juvenile rheumatoid arthritis

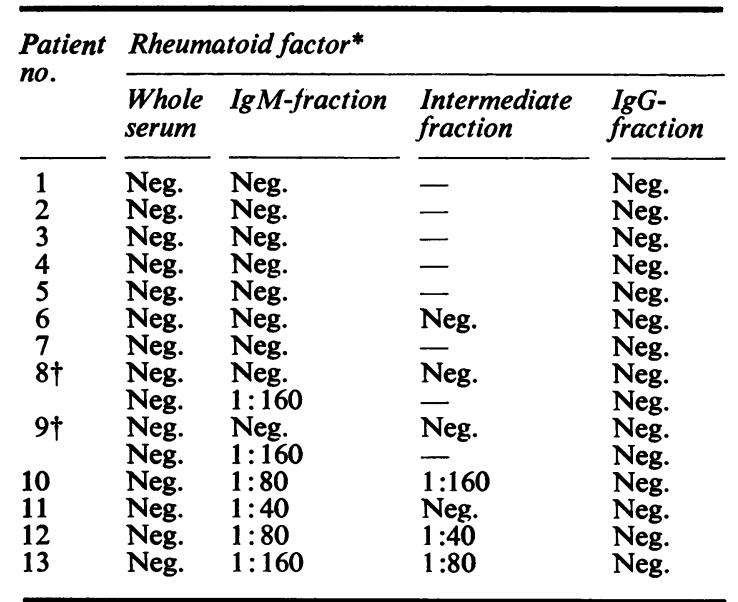

* Rheumatoid factor by latex test at a dilution of $1: 20$ or less was considered negative.

$\dagger$ Patients 8 and 9 were tested twice, i.e. in April and October, 1972. when they were tested again 6 months later. There was no concomitant change in their clinical status.

An attempt was made to correlate the occurrence of 'hidden' RF with clinical parameters. Five of six patients (83 per cent.) with 'hidden' RF also had antinuclear antibody (ANA), whereas only three of seven patients ( 43 per cent.) without 'hidden' RF had ANA. The presence of 'hidden' $R F$ was more frequent with earlier onset of disease, $4.3 \mathrm{yrs}$ in the 'hidden' RF group compared to $8.5 \mathrm{yrs}$; it was also more commonly found with longer duration of disease, $6 \cdot 0 v$. $4 \cdot 1$ yrs, respectively. No gross differences were noted in sex distribution, type of onset (pauciarticular or polyarticular), or severity of disease according to the criteria of Steinbrocker, Traeger, and Batterman (1949). The erythrocyte sedimentation rate (ESR) was essentially the same in both groups, although the value of patient 8 with 'hidden' RF was considerably higher.

\section{Discussion}

Why certain patients have only 'hidden' RF in their serum and others have RF detectable by the standard tests has never been adequately explained. 'Hidden' RF may be RF complexed to IgG so as to inhibit the reaction with the IgG on the latex or sensitized sheep cell reagents (Bluestone and others, 1969). It perhaps binds more avidly with IgG in the serum, as suggested by Allen and Kunkel (1966). It is also possible that RF reacts preferentially with a subpopulation of IgG that exists in limited supply. There is no compelling evidence for either possibility.

Since the incidence of conventional RF in JRA is low compared with that in rheumatoid arthritis of adult-onset (about $20 v .80$ per cent.) the possibility that 'hidden' RF might be more prevalent in JRA had to be considered. The present data show an incidence of 46 per cent. 'hidden' RF in thirteen seronegative patients with JRA. This figure is higher than the 20 per cent. incidence reported by Cracchiolo and others (1970) in seronegative patients with rheumatoid arthritis of adult onset, but it is based on a small number of patients and the difference may not be significant.

The use of increasingly sensitive means of detecting antiglobulin antibodies has made it possible to find RF in most latex-negative patients with rheumatoid arthritis of adult onset, albeit at the cost of increasingly high numbers of false positives. Similarly, the incidence of RF in JRA increases when specialized tests are used. Thus, Hall, Mednis, and Bayles (1958) showed 61.5 per cent. incidence of RF in JRA using a combination of tests including the sensitive euglobulin-inhibition test; Torrigiani, Ansell, Chown, and Roitt (1969) showed 100 per cent. incidence with a 
test based on immunoadsorption on cross-linked rabbit $\gamma$-globulin; and Estes, Atra, and Peltier (1973) showed 59 per cent. incidence using an immunofluorescent test. Unlike the latex test, which is very insensitive for the detection of IgG-RF, some of these tests effectively measure IgG-RF as well as IgM-RF. In the present study no attempt was made to increase the sensitivity of the standard latex test; in fact, the isolated fractions were concentrated to the original serum volume so as to obtain direct comparisons. Nevertheless, it is possible that some of the specialized tests might have revealed the 'hidden' RFs reported here. Conversely, it is possible that the four seronegative JRA patients with IgM antiglobulin activity found by Torrigiani and others (1969) actually represent cases of 'hidden' RF.

There have been only about twenty cases of 'hidden' RF reported, all except the ones presented here, in cases of rheumatoid arthritis of adult onset. Consequently, the clinical significance of 'hidden' RF is not known. An attempt to relate the presence of 'hidden' RF in our study to other parameters, such as sex, age at onset, duration of disease, type of onset, ESR, and ANA is hazardous because of the limited numbers of patients studied. It is of interest though that almost all patients with 'hidden' RF also had ANA while the reverse was not true. Similarly, 'hidden' RF was found more frequently in those individuals with an earlier age at onset and longer duration of disease. By contrast, reports in the literature show a good correlation between conventional RF in JRA and later age at onset, male sex, and the presence of rheumatoid nodules (Bywaters and others, 1959; Cassidy and Valkenburg, 1967; Hanson and others, 1969). According to Estes and others (1973), using an immunofluorescent assay, RF correlates with duration of disease but not with age at onset of disease.

\section{Summary}

The incidence of 'hidden' rheumatoid factor in seronegative juvenile rheumatoid arthritis was studied by subjecting the sera of thirteen patients to gel filtration on Sephadex G-200 at pH 4 and assaying the fractions (after dialysis and concentration to the original serum volume) for rheumatoid factor by the latex test. Six of the sera contained 'hidden' rheumatoid factor. Attempts to correlate the presence of 'hidden' rheumatoid factor with other parameters of the disease did not reveal any striking correlations, but patients with 'hidden' rheumatoid factor tended to have an earlier onset of disease, longer duration of disease, and a more frequent incidence of antinuclear antibodies.

\section{References}

Allen, J. C., AND KUnKel, H. G. (1966) Arthr. and Rheum., 9, 758 (Hidden rheumatoid factors with specificity for native gamma globulins)

Bluestone, R., Goldberg, L. S., AND Cracchiolo, A. (1969) Lancet, 2, 878 (Hidden rheumatoid factor in seronegative nodular rheumatoid arthritis)

Bywaters, E. G. L., Carter, M. E., AND Scott, F. E. T. (1959) Ann. rheum. Dis., 18, 225 (Differential agglutination titre in juvenile rheumatoid arthritis)

Cassidy, J. T., AND Valkenburg, H. A. (1967) Arthr. and Rheum., 10, 83 (A five year prospective study of rheumatoid factor tests in juvenile rheumatoid arthritis)

Cracchiolo, A., Bluestone, R., AND Goldberg, L. S. (1970) Clin. exp. Immunol., 7, 651 (Hidden antiglobulins in rheumatic disorders)

Estes, D., Atra, E., AND Peltier, A. (1973) Arthr. and Rheum., 16, 59 (An immunofluorescent method for the detection of antigammaglobulin antibodies)

Hall, A. P., Mednis, A. D., ANd Bayles, T. B. (1958) New Engl. J. Med., 258, 731 (The latex agglutination and inhibition reactions. Clinical experience in the diagnosis of rheumatoid arthritis)

Hanson, V., DreXler, E., AND KornReich, H. (1969) Arthr. and Rheum., 12, 82 (The relationship of rheumatoid factor to age of onset in juvenile rheumatoid arthritis)

Singer, J. M., AND Plotz, C. M. (1956) Amer. J. Med., 21, 888 (The latex fixation test. I. Application to the serologic diagnosis of rheumatoid arthritis)

Steinbrocker, O., Traeger, C. H., and Batterman, R. C. (1949) J. Amer. Med. Ass., 140, 659 (Therapeutic criteria in rheumatoid arthritis)

Torrigiani, G., Ansell, B. M., Chown, E. E. A., AND Roitt, I. M. (1969) Ann. rheum. Dis., 28, 424 (Raised IgG antiglobulin factors in Still's disease) 